\title{
Comparative proteomic analysis in serum of former uranium miners with and without radon induced squamous lung cancer
}

\author{
Simone Helmig ${ }^{* *}$ (D) Günter Lochnit ${ }^{2}$ and Joachim Schneider ${ }^{1}$
}

\begin{abstract}
Summary: Former uranium miners of the Wismut Company, East Germany, have been exposed to ionizing radiation from radon decay products and therefore were at high risk for lung cancer. Since histological types of cancer in the so called Wismut cohort revealed an association of high radon exposure with a higher relative frequency of squamous cell carcinoma (SqCC), we used comparative proteomic analysis to identify differentially expressed proteins in serum exposed uranium miners with SqCC.

Methode: Pooled sera of exposed former uranium miners without lung disease and pooled sera of former uranium miners with SqCC were analysed by 2-D gel electrophoresis. MALDI-TOF-MS was performed from reproducable, significantly, at least 5-fold up-regulated protein spots. Proteins were identified by MASCOT peptide mass fingerprint search. Additionally a receiver operating characteristic curve for CYFRA 21-1 was created.
\end{abstract}

Results: The protein spots were identified as Keratin 10 (K10), Keratin 1 (K1), complement factor $\mathrm{H}$ (CFH) and a haptoglobin (Hpt) fragment. The sensitivity for CYFRA 21-1 reveals 60\% at a specifity of 95 and $80 \%$ at a specifity of $80 \%$. Plotting the sensitivity against specifity reveals an AUC of 0.88 .

Conclusion: In SqCC Keratin 10 and 1 were strongly induced. This was associated with CYFRA 21-1, confirming the cytokeratin fragment as a tumormarker.

\section{Introduction}

Uranium minerals are associated with radioactive elements such as radium and radon in the ore which arise from the radioactive decay [1]. Radium decay due to emitted high-LET alpha-radiation has been found to be carcinogenic to humans [2]. Uranium underground miners are primarily exposed to internal ionizing radiation from radon decay products especially $\alpha$-emitters such as ${ }^{222} \mathrm{Rn},{ }^{218} \mathrm{Po},{ }^{214} \mathrm{~Pb},{ }^{214} \mathrm{Bi}$ and ${ }^{214} \mathrm{Po}$ and also to dust with high contents of crystalline silica via inhalation [3]. To a lesser extent, they are also exposed to uranium ore dust and to external $\gamma$-rays, both of which are important to consider for risk to organs other than lungs [1]. Uranium mining and processing with a total yield of 231,000 tones of Uranium took place by the Wismut Company, East Germany between the years 1946 and

\footnotetext{
* Correspondence: simone.helmig@arbmed.med.uni-giessen.de ${ }^{1}$ Institute and Outpatient Clinic for Occupational and Social Medicine, Justus-Liebig-University Giessen, Aulweg 129, D-35392, Giessen, Germany Full list of author information is available at the end of the article
}

1990. In this time period, approximately 500,000 to 600,000 employers were exposed to ionizing radiation during underground mining and uranium processing at the Wismut Company. The german federal ministry for the environment enabled the establishment of the so called Wismut cohort with about 59,000 male workers, which is currently worlwide the largest cohort of uranium mine workers (for review refer to [4]. The exposure were in the range from 30 to $300 \mathrm{WLM}^{*}$ per year and about $10-100 \mathrm{mg} / \mathrm{m}^{3}$ silica containing dust [3-5]. Especially in the first decade due to unsafe working conditions they were exposed to high radiation levels. With improvement of the working conditions in the later years the avarage exposure level was reduced. More than 20,000 cases of silicosis and more than 9000 cases of lung cancer arised from these working conditions [6]. With an increasing cumulative radon exposure and increasing silica dust exposure a statistically significant increase in mortality from lung cancer has been reported (for review refer to [4]. Even for low cumulative radon 
exposure a statistically significant association with lung cancer has been shown in Wismut uranium miners [7]. Investigations on the histological types of cancer in the Wismut cohort revealed an association of high radon exposure with a higher relative frequency of smal cell lung carcinoma (SCLC) and squamous cell carcinoma (SqCC) than adenocarcinomas (AC).

Lung carcinomas are frequent occupational cancers in Germany, whereof a great number is caused in Wismut uranium miners by ionizing radiation (so called "Schneeberger" lung cancer) [8]. Cancer is a result of a number of genetic alterations that disturb normal cell growth and differentiation [3]. It is reasonable that different causes of cancer act via different biological mechanisms that reflect the histoplogical subtypes. A pilot study investigating biomarkers with regard to lung cancer has been implemented earlier [9]. In the past decades, the investigating methods and possibilities have been envolving rapidly. Since histological types of cancer in the Wismut cohort revealed an association of high radon exposure with a higher relative frequency of squamous cell carcinoma ( $\mathrm{SqCC}$ ) we used modern technology i.e. comparative proteomic analysis to screen this cohort and to identify differentially expressed proteins in serum of former uranium miners without lung disease and uranium miners with SqCC. Comparative proteomic analysis may be able to identify differentially expressed proteins in serum of former uranium miners without lung disease and uranium miners with SqCC.

\section{Materials and methods \\ Subjects}

Within the framework of a former multi-center, molecular biology-based project, $n=106$ former uranium miners of SDAG Wismut (66.6 \pm 4.5 years; $15 \%$ current smokers, $80 \%$ ever smokers) without lung disease and $n=21$ former uranium miners of SDAG Wismut (67.5 \pm 5.8 years; $57 \%$ current smokers, $90 \%$ ever smokers) with lung cancer related to ionizing radiation (radon and its decay products) with accepted occupational disease (No. 2402 BKV) (criteria for diagnosis: see [10]) were included, (for detailed description refer to [3]. The histological classification of the lung cancers involves 15 squamous carcinomas, 2 adenocarcinomas, 2 small-cell carcinomas and 2 large-cell carcinomas. For the proteomic analysis within this study, only sera of highly exposed, former uranium miners without lung disease and those suffering from squamous cell carcinomas related to ionizing radiation (radon and its decay products) were examined. This is due to the small number of cancers other histological classification not suitable for proteomics discrimination and further statstical analysis. Former uranium miners of SDAG Wismut without lung disease are indicated as "former uranium miners without lung diesease" and former uranium miners of SDAG Wismut with sqouamous lung cancer are indicated as "uranium miners with SqCC".

The miners had started their work within the Wismut Company between 1946 and 1978, and over 50\% had stopped working as miners before 1980 . The mean time of employment at the company was 21.8 years (range: 0.4 bis 42.1 years). Work in the underground mine was for about 14.5 years, and exposure to ionising radiation in uranium processing was calculated at 7.4 years. $\mathrm{Cu}-$ mulative exposure in WLM* was calculated in each UM by ZeBWis (special department of the German Professional Associations for the observation of the health of former Wismut workers). The mean exposure was calculated at $612 \pm 500$ WLMs (range: $0,7-1954$ WLM) or $6.4 \pm 9.76 \mathrm{kBqh} / \mathrm{m}^{3}$ (range: $0.06-80 \mathrm{kBqh} / \mathrm{m}^{3}$ ) and 53.5 $\pm 101.7 \mathrm{mSv}$ (range: $0-874.3 \mathrm{mSv}$ ) respectively.

All sera were frozen following venipuncture and centrifugation, and stored in liquid nitrogen until analysis.

\section{Sample preparation}

Serum samples were clarified by centrifugation $(20,500 \times g$ for $20 \mathrm{~min}$ at $10^{\circ} \mathrm{C}$ ). One milliliter of the supernatant was applied to the Proteominer Enrichment Kit (large capacity kit, BioRAD) according to the manufacturer's instructions.

\section{Two-dimensional gel electrophoresis}

Detailed descriptions of laboratory methods and statsitical analysis are presented in Korfei et al. 2011 [11]. In brief: For 2-D gel electrophoresis proteins solubilized in $6 \mathrm{M}$ urea, $2 \mathrm{M}$ thiourea, $4 \%$ CHAPS, $1 \%$ DTT and $2 \%$ Pharmalyte 3-10. IPG-strips ( $\mathrm{pH} 3-10 \mathrm{nl})$ were rehydrated at $20^{\circ} \mathrm{C}$ with the protein extract. On each strip, 63 or $75 \mu \mathrm{g}$ proteins were applied and isoelectric focusing was performed with $32.05 \mathrm{kVh}$. After focusing, the IPG-strips were equilibrated for $10 \mathrm{~min}$ in $2 \mathrm{ml}$ equilibration stock solution (ESS; $6 \mathrm{M}$ urea, $0.1 \mathrm{mM}$ EDTA, $0.01 \%$ bromphenol blue, $50 \mathrm{mM}$ Tris- $\mathrm{HCl} \mathrm{pH} 6.8,30 \%$ glycerol) for $15 \mathrm{~min}$ in $2 \mathrm{ml}$ ESS I ( $10 \mathrm{ml}$ ESS containing $200 \mathrm{mg}$ SDS, $100 \mathrm{mg}$ DTT) followed by $15 \mathrm{~min}$ in ESS II (10 ml ESS containing $200 \mathrm{mg}$ SDS, $480 \mathrm{mg}$ iodacetamide). Protein separation in the second dimension was performed by electrophoresis on $12.5 \%$ SDS polyacrylamide gels according to Laemmli (Laemmli, 1970). Electrophoresis was carried out at least in duplicat using a Hoefer 600 system with the following program: $15 \mathrm{~min}$ at $15 \mathrm{~mA} /$ gel and $5 \mathrm{~h}$ at $110 \mathrm{~mA}$ at $25^{\circ} \mathrm{C}$. Gels were stained with Flamingo (BioRAD) and scanned with a Typhoon 9100 (GE Healthcare). Densitometric analysis of the gels was done with PDQuest (BioRAD). Protein spots present in all gels and showing statistical significant differences in abundance (five fold up-regulated) were selected for further analysis. 


\section{Tryptic in-gel digestion of proteins}

Stringent criteria such as spots must be present in all gels, spots must be at least five fold upregulated with at least 98\% confidence interval were applied to select spots. Selected spots were digested after reduction and carbamidomethylation with trypsin using an automated liquid handling system (MicroStarlet, HamiltonRobotics, Martinsried, Germany). Tryptic peptides were eluted from the gel plugs with $1 \%$ trifluoric acid.

\section{Matrix-assisted laser-desorption ionization time-of-flight mass spectrometry (MALDI-TOF-MS)}

MALDI-TOF-MS was performed on an Ultraflex TOF/ TOF mass spectrometer equipped with a nitrogen laser and a LIFT-MS/MS facility. The instrument was operated in the positive-ion reflectron mode using 2,5dihydroxybenzoic acid and methylendiphosphonic acid as matrix. Sum spectra consisting of 200-400 single spectra were acquired. For data processing and instrument control the Compass 1.4 software package consisting of FlexControl 3.4, FlexAnalysis 3.4 and BioTools 3.2 was used.

\section{Database search}

Proteins were identified by MASCOT peptide mass fingerprint search (http://www.matrixscience.com) using the NCBInr database $(20,140,811 ; 47,570,513$ sequences; $16,962,606,718$ residues; 247,733 human sequences) and Uniprot_human (20,151,014; 92,006 sequences; 36,592,947 residues). For the search a mass tolerance of $75 \mathrm{ppm}$ was allowed and carbamidomethylation of cysteine as global modification and oxidation of methionine as variable modification were used. A false positive rate of $5 \%$ was allowed.

\section{CYFRA 21-1}

Sera were kept frozen at $-18{ }^{\circ} \mathrm{C}$ until analysis was carried out. CYFRA 21-1 analyses were performed in sera using reagents from Roche Diagnostics ${ }^{\circledR} \mathrm{GmbH}$, Mannheim, Germany, and were measured with an $\mathrm{ES}^{\circledR}$ 600 ELISA analyzer (Roche ${ }^{\circledR}$, Mannheim, Germany).

\section{Results and discussion}

It is noteworthy that both comparison groups i.e. former uranium miners without lung disease and uranium miners with $\mathrm{SqCC}$ had significant occupational radiation exposures, which alleviates a potential bias, which would arise for the case with a control group without radiation exposure.

A full comparison of all protein spot visualized in three different proteome maps of sera from exposed healthy uranium miners and sera of uranium miners with $\mathrm{SqCC}$ was performed. In order to increase the specifity rather stringent criteria (present in all gels and at least five fold upregulated with with at least $98 \%$ confidence interval were applied. This approach revealed 5 protein spots which fullfilled the aforementioned criteria, while protein spots with a lower specifity were not considered within this study. The 5 protein spots could be identified by MALDI-TOF-MS after in-gel digestion (Table 1). A representative 2-D gel is shown in Fig. 1. The upregulated

Table 1 Database screening of MALDI-TOF-Analysis

\begin{tabular}{|c|c|c|c|c|c|c|}
\hline Spot no & Accession & Name & MW [kDa] & |Peptides & SC [\%] & Rank \\
\hline \multirow{6}{*}{4220} & gi|21961605 & Keratin 10 [Homo sapiens] & 58.8 & 19 & 31.2 & 1 \\
\hline & gi|178853 & apolipoprotein E [Homo sapiens] & 36.2 & 17 & 53.3 & 2 \\
\hline & F5HO39 & Gephyrin OS=Homo sapiens $\mathrm{GN}=\mathrm{GPHN} \mathrm{PE}=1 \mathrm{SV}=1$ & 84.7 & 17 & 26.0 & 4 \\
\hline & P02649 & Apolipoprotein E OS=Homo sapiens GN=APOE PE $=1$ SV=1 & 36.1 & 16 & 50.5 & 2 \\
\hline & P35908 & Keratin, type II cytoskeletal 2 epidermal OS=Homo sapiens $G N=K R T 2 P E=1 \quad S V=2$ & 65.4 & 16 & 34.4 & 3 \\
\hline & P13645 & Keratin, type I cytoskeletal $10 \mathrm{OS}=$ Homo sapiens $\mathrm{GN}=\mathrm{KRT} 10 \mathrm{PE}=1 \mathrm{SV}=6$ & 58.8 & 19 & 31.2 & 1 \\
\hline \multirow{5}{*}{4416} & gi|40737343 & C4B3 [Homo sapiens] & 47.4 & 14 & 32.0 & 1 \\
\hline & gi|119581085 & keratin 10 (epidermolytic hyperkeratosis; keratosis palmaris et plantaris), isoform CRA_b [Homo sapiens] & 63.3 & 16 & 23.7 & 4 \\
\hline & gi|40737466 & C4B1 [Homo sapiens] & 58.3 & 15 & 27.2 & 3 \\
\hline & gi|40737308 & C4B1 [Homo sapiens] & 47.5 & 14 & 32.0 & 2 \\
\hline & $\mathrm{P} 13645$ & Keratin, type I cytoskeletal $10 \mathrm{OS}=$ Homo sapiens $\mathrm{GN}=\mathrm{KRT} 10 \mathrm{PE}=1 \mathrm{SV}=6$ & 58.8 & 15 & 23.3 & 1 \\
\hline \multirow{3}{*}{4709} & gi|158517847 & RecName: Full=Complement factor $\mathrm{H}$; AltName: Full=H factor 1; Flags: Precursor [Homo sapiens] & 139.0 & 54 & 53.9 & 1 \\
\hline & gi|239781887 & Chain A, Solution Structure Of Human Complement Factor H In $50 \mathrm{Mm}$ Nacl Buffer & 136.9 & 54 & 55.6 & 2 \\
\hline & $\mathrm{P} 08603$ & Complement factor $\mathrm{H}$ OS=Homo sapiens $\mathrm{GN}=\mathrm{CFH} P E=1 \mathrm{SV}=4$ & 139.0 & 54 & 53.9 & 1 \\
\hline \multirow{19}{*}{5711} & gi|119581148 & keratin 9 (epidermolytic palmoplantar keratoderma) [Homo sapiens] & 57.5 & 22 & 36.9 & 10 \\
\hline & gi|307086 & keratin-10 [Homo sapiens] & 46.4 & 21 & 41.1 & 5 \\
\hline & gi|375314779 & keratin 1 [Homo sapiens] & 66.0 & 28 & 33.1 & 2 \\
\hline & gi|7331218 & keratin 1 [Homo sapiens] & 66.0 & 27 & 32.6 & 3 \\
\hline & gi|193787214 & unnamed protein product [Homo sapiens] & 46.9 & 20 & 37.6 & 11 \\
\hline & gi|386854 & type II keratin subunit protein, partial [Homo sapiens] & 52.8 & 23 & 27.8 & 8 \\
\hline & gi|47132620 & keratin, type II cytoskeletal 2 epidermal [Homo sapiens] & 65.4 & 22 & 36.0 & 6 \\
\hline & gi|21961605 & Keratin 10 [Homo sapiens] & 58.8 & 30 & 46.1 & 1 \\
\hline & gi|623409 & keratin 10 [Homo sapiens] & 57.2 & 24 & 43.0 & 4 \\
\hline & gi|167887748 & vimentin variant 4 [Homo sapiens] & 26.8 & 16 & 50.9 & 7 \\
\hline & gi|340234 & vimentin, partial [Homo sapiens] & 35.0 & 17 & 41.7 & 9 \\
\hline & P13645 & Keratin, type I cytoskeletal $10 \mathrm{OS}=$ Homo sapiens $\mathrm{GN}=\mathrm{KRT} 10 \mathrm{PE}=1 \mathrm{SV}=6$ & 58.8 & 30 & 46.1 & 1 \\
\hline & AOA087WZ84 & Zinc finger protein 568 OS=Homo sapiens GN=ZNF568 PE=4 SV=1 & 73.9 & 18 & 26.6 & 8 \\
\hline & BOYJC5 & Vimentin OS=Homo sapiens $G N=V I M P E=1 \quad S V=1$ & 26.8 & 16 & 50.9 & 4 \\
\hline & BOYJC4 & Vimentin OS=Homo sapiens GN=VIM PE=1 SV=1 & 49.6 & 20 & 35.5 & 5 \\
\hline & Q5JVS8 & Vimentin (Fragment) OS=Homo sapiens GN=VIM PE=1 SV=1 & 20.0 & 9 & 46.2 & 7 \\
\hline & Q3ZCX4-3 & Isoform 3 of Zinc finger protein 568 OS=Homo sapiens GN=ZNF568 & 66.6 & 17 & 28.4 & 6 \\
\hline & P04264 & Keratin, type II cytoskeletal $1 \mathrm{OS}=$ Homo sapiens $\mathrm{GN}=\mathrm{KRT} 1 \mathrm{PE}=1 \mathrm{SV}=6$ & 66.0 & 27 & 32.6 & 2 \\
\hline & P35908 & Keratin, type II cytoskeletal 2 epidermal OS=Homo sapiens $\mathrm{GN}=\mathrm{KRT} 2 \mathrm{PE}=1 \mathrm{SV}=2$ & 65.4 & 22 & 36.0 & 3 \\
\hline \multirow{6}{*}{6409} & gi|40737308 & C4B1 [Homo sapiens] & 47.5 & 14 & 33.6 & 1 \\
\hline & E9PIS9 & THAP domain-containing protein 1 (Fragment) $O S=$ Homo sapiens $G N=T H A P 1 P E=1 S V=1$ & 13.9 & 4 & 45.8 & 1 \\
\hline & gi|296653 & hp2-alpha [Homo sapiens] & 41.5 & 11 & 25.7 & 1 \\
\hline & J3КTC3 & Haptoglobin-related protein OS=Homo sapiens $\mathrm{GN}=\mathrm{HPR} P E=1 \mathrm{SV}=1$ & 13.3 & 7 & 45.3 & 3 \\
\hline & J3KRH2 & Haptoglobin (Fragment) OS=Homo sapiens $\mathrm{GN}=\mathrm{HP} P E=1 \mathrm{SV}=1$ & 16.6 & 8 & 47.0 & 1 \\
\hline & P00738 & Haptoglobin $\mathrm{OS}=$ Homo sapiens $\mathrm{GN}=\mathrm{HP} P E=1 \mathrm{SV}=1$ & 45.2 & 11 & 23.6 & 2 \\
\hline
\end{tabular}




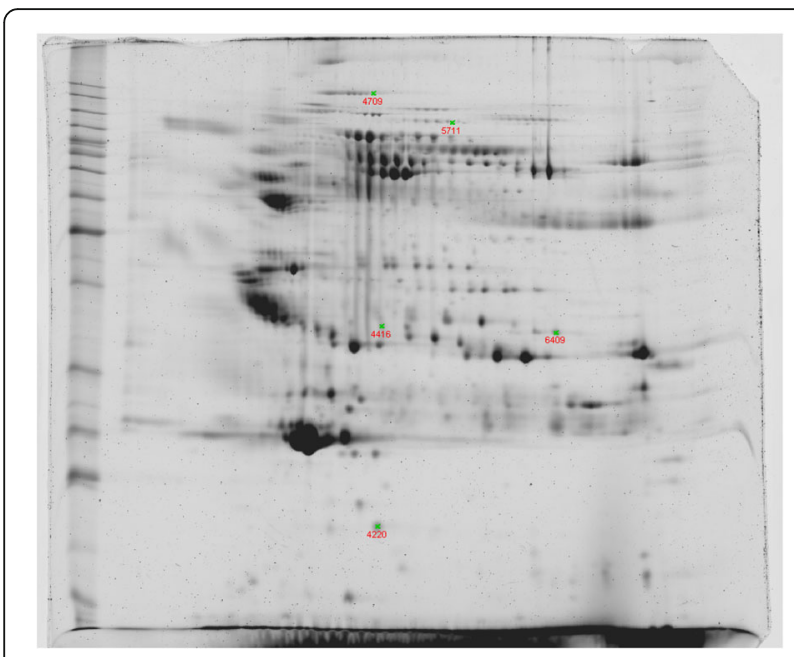

Fig. 1 Representative 2-DE map of $75 \mu \mathrm{g}$ of protein extracted from sera of uranium miners with SqCC. Separation of extracted protein was performed on linear strip with a $\mathrm{pH}$ range of 3-10 followed by 12,5 SDS-PAGE. Gels were stained with FLAMINGO (BioRad). 2D gels were scanned and differences in protein abundance were detected using Proteomweaver software. Proteins that differed more than or equal to 5 -fold and were identified are marked

protein spots were identified as Keratin 10 (K10), Keratin 1 (K1), complement factor $\mathrm{H}(\mathrm{CFH})$ and a haptoglobin (Hpt) fragment. Information about the identification of these differentially expressed protein spots is provided in Table 2.

A very important aspect of this study is the evidence of increased keratins $\mathrm{K} 1$ and $\mathrm{K} 10$ in the serum of uranium miners with SqCC. Keratins are intermediatefilament-forming proteins, which are primarily expressed in epithelial cells [12]. Human keratins represent the type I keratins $\mathrm{K} 9-\mathrm{K} 10, \mathrm{~K} 12-\mathrm{K} 28$, and $\mathrm{K} 31-\mathrm{K} 40$ and the type II keratins K1-K8 and K71-K86 [13]. Since tumors usually retain the keratin patterns of their epithelial origin, their keratin patterns are being used for cell and tumor typing. Additionally, keratins are often used as epithelial differentiation and tumor markers [13]. Keratin expression of $\mathrm{K} 1$ and $\mathrm{K} 10$ is assigned especially to the postmitotic suprabasal epidermal cells, wereas the proliferative basal cell layers show different expression patterns (K5, K14, K15) [13]. Besides maintaining the mechanical integrity, K10 also inhibits proliferation and cell cycle progression of keratinocytes [14, 15]. The loss of $\mathrm{K} 10$ results in a increased keratinocyte turnover (for review, see [16]. K1 and K10 seem to be focally expressed in suprabasal cells of internal noncornifying stratified squamous epithelia. Especially in relation to maturation and keratiniziation focal expression of $\mathrm{K} 1$ and $\mathrm{K} 10$ can be seen in squamous cell carcinomas of internal organs and skin (for reference, see [17]. K1 and K10 so far have not been applied for tumor diagnostic but can be regarded as "keratinozation markers" of keratinocytes [13]. Using commercially available ELISA kits did not achieve usable results for the detection of K1, K10 and Vimetin in sera of exposed uranium miners. Investigating sera and controls by western blot analysis using different antibodies (i.a. Fa. Abcam) revealed varying results in dependence of the applied antibody. Therefore these results were not applicable. Soluble keratin fragments released by carcinoma cells (mainly $\mathrm{K} 8, \mathrm{~K} 18$, and K19 fragments) in the serum of cancer patients are used to monitor disease progression in the case of certain carcinomas such as non-small cell lung cancer (NSCLC) $[18,19]$. For example increased concentrations of CYFRA 21-1, a water-soluble K19 fragment, are present in tumors of squamous origin, including the lung [20]. The highest sensitivity, between 40\% [21] and $100 \%$ [22] was reported for SqCC, whereby the sensitivity rises with the progression of the disease [20]. Not only the diagnostic but also the predictive and prognostic value of CYFRA 21-1 for advanced NSCLC has been reported [23]. Within the previously described cohort of former uranium miners of SDAG Wismut a receiver operating characteristic curve for CYFRA 21-1 was created (see Fig. 2). The sensitivity for CYFRA 21-1 in the uranium miners suffering from squamous cell carcinomas related to ionizing radiation reveals $60 \%$ at a specificity of 95 and $80 \%$ at a specificity of $80 \%$. Plotting the true positive rate (sensitivity) against the true negative rate (specificity) reveals an area under the curve (AUC) of 0.88. Therefore CYFRA 21-1 confirmed as a serum biomarker in SqCC.

Further markers such as the tumor suppressor gene product $\mathrm{p} 53$, the epidermal growth factor receptor (EGF-R) or Anti-p53 antibodies could not be identified within this study and in concordance with former results are not useful as serum biomarkers for detection of lung cancers due to ionizing radiation [3].

The complement system is a cascade of functionally related proteins, which mediate the immune respose

Table 2 Proteins significantly up-regulated in SqCC relative to healthy controls

\begin{tabular}{lllccccc}
\hline Spot no. & Accession no. & Protein name & MW [kDa] & Peptides & SC [\%] & Rank & Mascot Score \\
4220 & gi|21961605 & Keratin 10 & 58.8 & 19 & 31.2 & 1 & 85.4 \\
4416 & gi|119581085 & Keratin 10 & 63.3 & 16 & 23.7 & 4 & 75.0 \\
4709 & gi|158517847 & Complement factor H & 139.0 & 54 & 53.9 & 1 & 322.0 \\
5711 & gi|375314779 & Keratin 1 & 66.0 & 28 & 33.1 & 2 & 122.0 \\
6409 & J3KRH2 & Haptoglobin (Fragment) & 16.6 & 8 & 47.0 & 1 & 97.4 \\
\hline
\end{tabular}




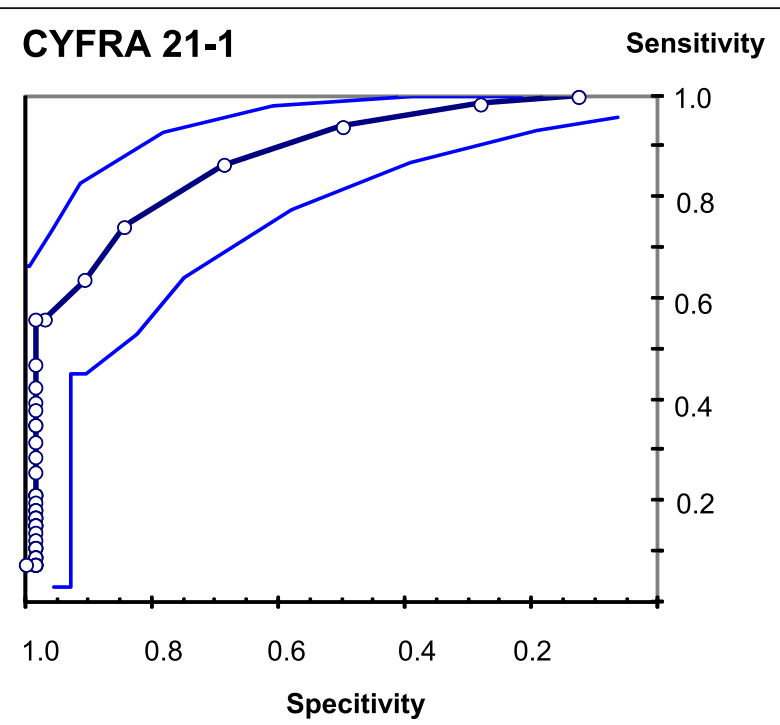

Fig. 2 ROC of CYFRA 21-1. Receiver operating characteristic curves (ROC) and confidence intervals comparing the performance of CYFRA 21-1-measurements in sera of 108 healthy uranium miners and in sera of 18 uranium miners with squamous cell carcinoma. AUC (Area under curve) $=0.88$

leading in consequence to cell lysis. The activation of this system is highly controlled by several regulatory proteins. Human complement factor $\mathrm{H}(\mathrm{CFH})$, is a member of the regulators of complement activation family and plays a central role in the inhibition of the activation of the alternative pathway [24, 25]. Especially human NSCLC cells have the ability to circumvent the complement mediated immune response and are resistant to complement mediated cell lysis [26]. There is some evidence suggesting the involvement of $\mathrm{CFH}$ in carcinogenesis by demonstrating a protective role for $\mathrm{CFH}$. For example a high expression of $\mathrm{CFH}$ was shown in most non-small cell lung cancer cell lines with a protective effect against complement activation [24]. Evidence for a role of $\mathrm{CFH}$ in squamous cell cancer of skin (CSCC) progression has been provided and $\mathrm{CFH}$ has been suggested as progression marker and potential therapeutic target in CSCC [27]. CFH has also been suggested as a diagnosic marker for lung adenocarcinoma and transitional cell cancer of the bladder [25, 28]. The use of monoclonal antibody proteomics of a panel of biomarkers, showed statistically significant differences for five biomarkers including $\mathrm{CFH}$ and haptoglobulin (Hpt) in the plasma of NSCLC patients $(N=301)$ vs. healthy controls $(N=235)$ [29]. Examination of the complement system is clinically relevant in various immune complex diseases, such as systemic lupus erythematosus, vascular inflammations, glomerulonephritis or angioneurotic edema. Therefore the $\mathrm{CFH}$ is rather not a specific diagnostic maker for lung cancer diseases.
The comparison of serum from patients with a newly diagnosed NSCLC to serum from healthy controls, by using 2-dimensional difference gel electrophoresis (2D-DIGE), identified haptoglobin $(\mathrm{Hp})$ and glycan-modified derivatives as differentially expressed proteins. Therefore haptoglobin (Hp) and glycan-modified derivatives were suggested to be potentially useful markers for the clinical diagnosis of NSCLC [30]. Comparing serum proteomic profiles of 11 SCC patients, 7 chronic obstructive pulmonary disease (COPD) patients and 7 healthy smokers as controls identified the HP peptide HP216 as a promising cancer biomarker for the early detection of SCC in high risk lung cancer populations, including COPD patients and heavy smokers [31]. Using 2-D liquid phase fractionation system (PF2D) and mass spectrometry $\mathrm{Hp}$ reached a sensitivity of $89 \%$ and an AUC of 0.929 for lung adenocarcinomas when the cohort was restricted to male subjects [32]. Hp is an acute phase protein that scavenges haemoglobin released into circulation for example during haemolitic processes. The plasma concentration increases clearly during inflammation such as infections, injury or malignancy [33]. IL-6 is an major inducer of this protein [34]. Therefore, an increased Hpt serum concentration is an unspecific marker for inflammation, wereas a decreased $\mathrm{Hp}$ serum concentration is an marker for haemolytic processes.

\section{Conclusion}

In this study the evidence of increased keratins $\mathrm{K} 1$ and $\mathrm{K} 10$ in the serum of uranium miners with radiation-induced $\mathrm{SqCC}$ is notable. $\mathrm{K} 10$ and $\mathrm{K} 1$ may be valuable for tumor diagnosis in sera. As a surrogat cytokeratin fragment CYFRA 21-1 proofed to be an established serum biomarker for SqCC. The upregulated proteins CFH and Hpt are rather non-specific diagnostic makers for lung cancer diseases.

\section{Acknowledgements \\ We would like to thank all participants in the survey.}

\section{Funding}

There was no commercial funder. This work was supported by the JustusLiebig University of Gießen ( $J U$ ) in the framework of the Open Access Publishing Program. All authors are employees of the Federal University in Giessen.

Availability of data and materials

All detailed data and materials is available from corresponding author upon request.

\section{Authors' contributions}

SH provided the conception and design, and drafted the manuscript as well as participated in data analysis and interpretation of data. GL performed the proteomic analysis and participated in data analysis and interpretation of data. JS was involved in the acquisition of participants, provided the conception and design, data analysis and interpretation, writing and revising the manuscript. All authors read and approved the final manuscript.

Ethics approval and consent to participate

Former German uranium miners were offered a medical surveillance programme (including laboratory parameters, $x$-ray examination of the lungs, lung function and examination) by the ZeBWis (Zentrale Betreuungsstelle Wismut), a special 
department of the German Occupational Accident Insurance Associations responsible for health care and support of former SAG/SDAG Wismut employees. The German federal ministry for the environment enabled the establishment of the so called Wismut cohort to preserve the health data. A multicenter project investigating biomarkers with regard to lung cancer has been implemented and published earlier. All participants gave their consent to this project. At that time no ethical approval was required since the individuals participated voluntarily in the study. All data were analyzed anonymously. In the present study only former data and already frozen sera were analysed with modern laboratory methods, which were not available at that time. For the purpose of assessment and quality assurance no further ethic votes were required.

\section{Consent for publication}

The manuscript does not contain individual person's data in any form.

\section{Competing interests}

The Authors declare that they have no competing interests.

\section{Publisher's Note}

Springer Nature remains neutral with regard to jurisdictional claims in published maps and institutional affiliations.

\section{Author details}

${ }^{1}$ Institute and Outpatient Clinic for Occupational and Social Medicine, Justus-Liebig-University Giessen, Aulweg 129, D-35392, Giessen, Germany. ${ }^{2}$ Institute of Biochemistry, Friedrichstraße 24, Justus-Liebig-University Giessen, D-35392, Giessen, Germany.

Received: 19 September 2018 Accepted: 26 February 2019

Published online: 15 March 2019

\section{References}

1. Zablotska LB, Fenske N, Schnelzer M, Zhivin S, Laurier D, Kreuzer M. Analysis of mortality in a pooled cohort of Canadian and German uranium processing workers with no mining experience. Int Arch Occup Environ Health. 2018;91(1):91-103. Epub 2017/09/25.

2. Ionizing radiatin IARC. Part 2: Some internally deposited radionuclides. Monographs on the evaluation of carcinogenic risks to humans vol 78: International Agency for Research on Cancer. 2001:1-563.

3. Schneider J, Presek P, Braun A, Woitowitz HJ. Serum levels of pantropic p53 protein and EGF-receptor, and detection of anti-p53 antibodies in former uranium miners (SDAG Wismut). Am J Ind Med. 1999;36(6):602-9. Epub 1999/11/16

4. Walsh L, Grosche B, Schnelzer M, Tschense A, Sogl M, Kreuzer M. A review of the results from the German Wismut uranium miners cohort. Radiat Prot Dosim. 2015;164(1-2):147-53 Epub 2014/10/01.

5. Bauer HD. Potential dust exposures in underground mines of the former Wismut Itd. during early phase of uranium mining after the second world war. Gefahrstoffe Reinh Luft. 1997;57:349-54.

6. Schuttmann W. Schneeberg lung disease and uranium mining in the Saxon Ore Mountains (Erzgebirge). Am J Ind Med. 1993;23(2):355-68 Epub 1993/02/01.

7. Kreuzer M, Fenske N, Schnelzer M, Walsh L. Lung cancer risk at low radon exposure rates in German uranium miners. Br J Cancer. 2015;113(9):1367-9 Epub 2015/09/24.

8. Schneider J, Presek P, Braun A, Bauer P, Konietzko N, Wiesner B, et al. p53 protein, EGF receptor, and anti-p53 antibodies in serum from patients with occupationally derived lung cancer. Br J Cancer. 1999;80(12):1987-94. Epub 1999/09/02.

9. Popp W, Plappert U, Muller WU, Rehn B, Schneider J, Braun A, et al. Biomarkers of genetic damage and inflammation in blood and bronchoalveolar lavage fluid among former German uranium miners: a pilot study. Radiat Environ Biophys. 2000;39(4):275-82. Epub 2001/02/24.

10. Eigenwillig GG. Berufliche Strahlenexposition durch Radon und dessen Folgeprodukte. Konsequenzen für die Anerkennung als Berufskrankheit. Deutsches Ärtzeblatt. 1997;94:1057-62.

11. Korfei M, Schmitt S, Ruppert C, Henneke I, Markart P, Loeh B, et al. Comparative proteomic analysis of lung tissue from patients with idiopathic pulmonary fibrosis (IPF) and lung transplant donor lungs. J Proteome Res. 2011;10(5):2185-205 Epub 2011/02/16.

12. Jacob JT, Coulombe PA, Kwan R, Omary MB. Types I and II keratin intermediate filaments. Cold Spring Harb Perspect Biol. 2018;10(4) Epub 2018/04/04.
13. Moll R, Divo M, Langbein L. The human keratins: biology and pathology. Histochem Cell Biol. 2008;129(6):705-33 Epub 2008/05/08.

14. Paramio JM, Casanova ML, Segrelles C, Mittnacht S, Lane EB, Jorcano JL. Modulation of cell proliferation by cytokeratins K10 and K16. Mol Cell Biol. 1999;19(4):3086-94 Epub 1999/03/19.

15. Koch PJ, Roop DR. The role of keratins in epidermal development and homeostasis--going beyond the obvious. J Invest Dermatol. 2004;123(5):x-xi Epub 2004/10/16.

16. Magin TM, Vijayaraj $P$, Leube RE. Structural and regulatory functions of keratins. Exp Cell Res. 2007;313(10):2021-32. Epub 2007/04/17.

17. Moll R. Cytokeratins as markers of differentiation in the diagnosis of epithelial tumors. Subcell Biochem. 1998;31:205-62 Epub 1999/02/05.

18. Barak V, Goike H, Panaretakis KW, Einarsson R. Clinical utility of cytokeratins as tumor markers. Clin Biochem. 2004;37(7):529-40 Epub 2004/07/06.

19. Linder S. Cytokeratin markers come of age. Tumour biology : the journal of the International Society for Oncodevelopmental Biology and Medicine. 2007;28(4):189-95. Epub 2007/08/25.

20. Schneider J. Tumor markers in detection of lung cancer. Adv Clin Chem. 2006:42:1-41 Epub 2006/11/30.

21. Niklinski J, Furman M, Chyczewska E, Chyczewski L, Rogowski F, Jaroszewicz E, et al. Evaluation of CYFRA 21-1 as a new marker for non-small cell lung cancer. Eur J Cancer Prev. 1994;3(2):227-30. Epub 1994/03/01.

22. Koga H, Eguchi K, Shinkai T, Tamura T, Ohe Y, Oshita F, et al. Preliminary evaluation of the new tumor marker, CYFRA 21-1, in lung cancer patients. Jpn J Clin Oncol. 1994;24(5):263-8. Epub 1994/10/01.

23. Takeuchi A, Oguri T, Sone $K$, Ito $K$, Kitamura $Y$, Inoue $Y$, et al. Predictive and prognostic value of CYFRA 21-1 for advanced non-small cell lung Cancer treated with EGFR-TKIs. Anticancer Res. 2017;37(10):5771-6. Epub 2017/10/07.

24. Ajona D, Castano Z, Garayoa M, Zudaire E, Pajares MJ, Martinez A, et al. Expression of complement factor $\mathrm{H}$ by lung cancer cells: effects on the activation of the alternative pathway of complement. Cancer Res. 2004; 64(17):6310-8. Epub 2004/09/03.

25. Cui T, Chen Y, Knosel T, Yang L, Zoller K, Galler K, et al. Human complement factor $\mathrm{H}$ is a novel diagnostic marker for lung adenocarcinoma. Int $J$ Oncol. 2011;39(1):161-8 Epub 2011/04/20.

26. Varsano S, Rashkovsky L, Shapiro H, Ophir D, Mark-Bentankur T. Human lung cancer cell lines express cell membrane complement inhibitory proteins and are extremely resistant to complement-mediated lysis; a comparison with normal human respiratory epithelium in vitro, and an insight into mechanism(s) of resistance. Clin Exp Immunol. 1998;113(2):173-82. Epub 1998/08/26.

27. Riihila PM, Nissinen LM, Ala-Aho R, Kallajoki M, Grenman R, Meri S, et al. Complement factor $\mathrm{H}$ : a biomarker for progression of cutaneous squamous cell carcinoma. J Invest Dermatol. 2014;134(2):498-506 Epub 2013/08/14.

28. Kinders $\mathrm{R}$, Jones $\mathrm{T}$, Root R, Bruce $\mathrm{C}$, Murchison H, Corey M, et al. Complement factor $\mathrm{H}$ or a related protein is a marker for transitional cell cancer of the bladder. Clinical cancer research : an official journal of the American Association for Cancer Research. 1998;4(10):2511-2520. Epub 1998/10/31.

29. Guergova-Kuras M, Kurucz I, Hempel W, Tardieu N, Kadas J, Malderez-Bloes C, et al. Discovery of lung cancer biomarkers by profiling the plasma proteome with monoclonal antibody libraries. Molecular \& cellular proteomics : MCP. 2011;10(12):M111 010298 Epub 2011/09/29.

30. Hoagland LFM, Campa MJ, Gottlin EB, Herndon JE 2nd, Patz EF Jr. Haptoglobin and posttranslational glycan-modified derivatives as serum biomarkers for the diagnosis of nonsmall cell lung cancer. Cancer. 2007; 110(10):2260-8 Epub 2007/10/06.

31. Okano T, Seike M, Kuribayashi H, Soeno C, Ishii T, Kida K, et al. Identification of haptoglobin peptide as a novel serum biomarker for lung squamous cell carcinoma by serum proteome and peptidome profiling. Int J Oncol. 2016; 48(3):945-52 Epub 2016/01/20.

32. Chang YK, Lai YH, Chu Y, Lee MC, Huang CY, Wu S. Haptoglobin is a serological biomarker for adenocarcinoma lung cancer by using the ProteomeLab PF2D combined with mass spectrometry. Am J Cancer Res. 2016;6(8):1828-36. Epub 2016/09/21.

33. Quaye IK. Haptoglobin, inflammation and disease. Trans R Soc Trop Med Hyg. 2008;102(8):735-42 Epub 2008/05/20.

34. Oliviero S, Morrone G, Cortese R. The human haptoglobin gene: transcriptional regulation during development and acute phase induction. EMBO J. 1987:6(7):1905-12. Epub 1987/07/01. 